\title{
Participation of Housewives in Prevention of Dengue Hemorrhagic Fever in Sub-District Muara Dua, Lhokseumawe, Aceh, Indonesia
}

\author{
Wahyu Ajisah ${ }^{1}$, Irnawati Marsaulina ${ }^{2}$, R. Kintoko Rochadi ${ }^{1}$ \\ ${ }^{1}$ Department of Health and Behavior Science, Universitas Sumatera Utara, Medan, Indonesia \\ ${ }^{2}$ Department of Environment Health, Universitas Sumatera Utara, Medan, Indonesia \\ Email: ajisahwahyu@gmail.com
}

\begin{abstract}
:
Indonesia is a dengue endemic area and it has an epidemic once in 4-5 years. Until now it tends to increase in number of cases as well as its widespread. Researchers investigated that sociodemography, knowledge and attitudes related to dengue disease affecting the participation of housewives in prevention of dengue fever dengue mosquito through questionnaires and interviews. This research was conducted descriptively with cross sectional approach to 72 housewives in subdistrict Muara Dua, Lhokseumawe, Aceh, Indonesia using sample purposive sampling process. The relationship between the characteristics of housewives with their involvement in prevention of Dengue Hemorrhagic Fever (DHF) was analyzed using Pearson correlation analysis. More than $75 \%$ of respondents live in endemic areas and over $68 \%$ of respondents knew that dengue is transmitted through mosquitoes. 50\% of respondents knew that 3M (draining the water reservoir, closing the water reservoir and burying the garbage) Plus as DHF prevention but only $37.5 \%$ of respondents have applied $3 \mathrm{M}$ Plus even though they know that it needs to be continuously done throughout the year especially in the rainy season. The respondents' participation in prevention of DHF disease in moderate category was 50 respondents $(69.44 \%), 9$ respondents $(12.5 \%)$ were categorized as low in participation and only 13 respondents (18.06\%) were categorized as very good in participation in the effort to eliminate DHF. There was a highly significant correlation between knowledge and attitude $(p<0.01)$ and there was a significant correlation in education ( $p$ $<0.05)$ of housewives with their actions in the prevention of dengue hemorrhagic fever. This reflects the urgent need for advocacy programs in raising awareness of DHF in the community. The nearest inter-sector collaborates with the medical, veterinary, community and local authority sectors to ensure the availability of DHF prevention services besides $3 M$ Plus, also a monitoring officer/home and public health service to undertake health promotion programs of DHF prevention. This is a key element to eliminate deaths from dengue fever which occur every year.
\end{abstract}

Keywords:

participation; prevention of dengue fever; health promotion

\section{Introduction}

Dengue Hemorrhagic Fever (DHF) is a type of acute febrile illness. Case Fatality Rate (CFR) reaches $100 \%$ by attacking all ages and genders (Arikunto, 2013). This disease is caused by viral infections of the genus Flavivirus (Astuti, 2014) and 99\% of it are transmitted to humans by the bite of Aedes Aegypti and Aedes Albopictus. Although dengue hemorrhagic fever can be prevented, dengue fever has reached 2.5 billion, especially those living in urban areas in tropical and subtropical countries. Around 1.3 billion or $52 \%$ of the population are in the Southeast Asian region, estimated at around 2.9 million cases Dengue hemorrhagic fever (DHF) with 5,906 deaths occurring in Southeast Asia each year, especially children who are often the target of dengue disease (Candra, 2013). In this region, Indonesia has the highest number of DHF cases after India, China, Bangladesh and Pakistan with 71,668 cases reported 
per year with 641 of them dying (CDC, 2014). Directorate of Vector and Zoonotic Disease Control from The Ministry of Health continues to coordinate with the regions, especially in monitoring and intensifying dengue surveillance [5]. Previously, ASEAN countries had committed "ASEAN DENGUE DAY" for the elimination of dengue fever transmitted by Aedes Aegypti and Aedes Albopictus mosquitoes [6]. Indonesia is an endemic area of dengue and has an epidemic once in 4-5 years. Up to now, it tends to increase in number of cases as well as its widespread. In 2017, Indonesia Health Profile (IHP) reported that the number of cases of dengue hemorrhagic fever in Indonesia in 2016 was 201,885 cases (Incidence Rate $=$ 77.96 per 100,000 of population) with 1,585 deaths (CFR $=0.79 \%$ ). The highest Incidence Rate is in Bali Province, which is 484.02 per 100,000 of population, while the highest Case Fatality Rate (CFR) is in Maluku Province which is $5.79 \%$. IHP also informs about the number of Dengue Hemorrhagic Fever cases in Sumatra Province North in 2016 as many as 8,618 cases (Incidence Rate $=61.11$ per 100,000 of population) with 46 deaths (CFR = 0.53\%) (Kementerian Kesehatan Republik Indonesia, 2017).

The incidence of DHF in Aceh Province in 2012-2014 was 51\%, decreased by 29\%, and increased by 45\%. Data collected by Aceh Provincial Health Office showed that DHF cases fluctuate in various regions each year. Distribution of dengue cases in Lhokseumawe, Banda Aceh and Aceh Besar District in 2012-2014 respectively as follows: Lhokseumawe 300, 258, 128 cases; City of Banda Aceh 506, 258, 128 cases and Aceh Besar District 376, 156, 261 cases. Wiggle-Free Numbers (ABJ) in 2012-2014 Banda Aceh City 75.9\%, 74.5\% and 70.8\%; Lhokseumawe City 74.1\%, 84.4\% and 82.6\%; Aceh Besar District 73.3\%, 70.6\% and 85\% .2 DBD sufferers reported 1,510 cases in Aceh Province in 2015 with 6 deaths. Increased in 2016, which is 2,651 cases with a total of 26 deaths [7]. Based on data from the Health Office Banda Aceh, the number of cases dengue fever in Aceh has fluctuated in the past 5 years. The number of infected people in 2012 was 506 cases, 258 cases in 2013, and then in 2014 the number increased to 299. In 2015 only 127 cases and 2016 increased slightly by 152 cases. While data up to March 2017 the number of dengue fever patients has reached 148 cases and one patient died, DHF also has an impact or loss which called social and economic losses. Social losses occur among others caused by panic attack in the family, death of family members and the reduction of life expectancy. Direct impact on DHF patients is medical costs, while indirect impacts are loss of work and school time and other costs incurred in addition to treatment such as transportation and accommodation of patients during medication and treatment.

Various activities carried out by the Health Service in the effort to control DHF are promotion and situational activities namely early warning of DHF. The most effective prevention and eradication of DHF is by eradicating vector/larvae known as dengue mosquito eradication (DHF DBN) with its activities namely $3 \mathrm{M}$ that is sustainable. The number of larva-free $(\mathrm{ABJ})$ is expected to reach $95 \%$, so that the transmission of dengue disease will be difficult. The DBN PSN effort is directed towards the implementation by the community with a model of community participation that is in accordance with local conditions and culture. Thus the community is responsible and develops positive contributions to the prevention of DHF. The success of prevention and control of dengue requires community participation. At the family level, parents, especially mothers, who have a role to manage the household need to have good knowledge and have a will to be participated in the prevention and control of the disease. This is due to mothers who play a role and care for children who suffer from dengue. Based on the results of the preliminary survey, Muara Dua Public Health Center in Lhokseumawe City showed that the total population of 68,681 people consisted of 33,269 
men and 34,679 women, while there were 13,754 households in 17 villages. Data of patient visits from January-December 2017 were 8867 people.

Based on data obtained from the Muara Dua Health Center in Lhokseumawe City, the number of dengue fever sufferers during the last 3 years has fluctuated. In 2015 the number of sufferers was 38 cases with Incidence Rate (IR) of 78.2\% and Case Fatality Rate (CFR) of $2.7 \%$. In 2016 there were 35 cases with IR of $63.7 \%$ and CFR of $0.8 \%$. The year 2017 increased sharply to as many as 106 cases with IR namely $215.6 \%$ and CFR which is $1.0 \%$. The high number of dengue cases in the work area of Muara Dua Public Health Center is caused by several factors. One of the factors that contributed to the increase in dengue was the lack of participation of housewives in the control of dengue. Low maternal participation in the prevention of DHF can increase the occurrence of DHF in children and other family members. The observations that the researchers did in Muara Dua Subdistrict, Lhokseumawe City, that the lack of maternal participation in preventing DHF such as not taking action to close clean water reservoirs, not regularly draining water in the bath, not burying used goods that became water reservoirs and did not sprinkle abate powder. Some mothers also do not clean the house or yard regularly so that the house looks less clean. Community social participation in this case the mother is a form of participation in social activities in the community to prevent dengue fever so that it does not spread to family members.

The capability of understanding socio-demographics of society, knowledge and attitudes is important for DHF prevention and control programs to determine participation and its influence on post-exposure treatment seeking behavior. Several studies have been conducted to understand the knowledge, attitudes and perceptions for DHF such as in Thailand [10], Africa [11], India [12], Indonesia [13] and in the eastern Mediterranean [14]. The Indonesian government has implemented the $3 \mathrm{M}$ Plus and PSN (mosquito eradication) campaign and also "one monitoring officer/house" campaign. However, their level of participation in DHF prevention is still low.

This study aims to investigate and analyze the characteristics of housewives that influence the participation in coping in the estuary sub-district of the two cities in Lhokseumawe. This study will provide thought to continuously improve and formulate policies and activity plans from the control program for DHF because of its importance as basic information to support the elimination of human deaths due to dengue globally. The results of this study can be used as reading material and reference to be rational thinking for further research.

\section{Research Method}

This research was carried out descriptively with a cross sectional approach in Muara Dua, Lhokseumawe sub-district from October 2017 to May 2018, using a questionnaire consisting of three parts about socio-demography, knowledge, attitude and participation. All answered questionnaire were tabulated and classified. All answers were then scored based on the course of the question to measure the knowledge and attitude variables including interval scale 1 to 3 each with less, medium and good assessment criteria. The study population was all housewives in Muara Dua Subdistrict, Lhokseumawe City, totaling 898 from 17 villages. The sampling process was carried out purposively based on data from the Lhokseumawe City Health Office and the Lhokseumawe City Central Bureau of Statistics and the Muara Dua Public Health Center in Lhokseumawe City. The total sample is 72 housewives who have met the inclusion and exclusion criteria. The collected data were analyzed descriptively to draw 
conclusions about socio-demography, knowledge, attitudes to prevention of dengue disease that affect maternal participation. The relationship between characteristics of housewives and participation in the prevention of DHF were analyzed using Pearson correlation analysis.

\section{Discussion}

\subsection{Socio-Demographic Characteristics of Housewives}

The questionnaires have been distributed to 72 housewives and they were also being interviewed. From the interview and answered questionnaires, the socio demographic characteristics of the respondents are shown as follows: The majority of respondents are women (63.9\%); adults between the ages of $25-49$ years $(83.3 \%)$; Islam $(90.2 \%)$; and ethnic Acehnese (87.5\%). Most of the respondents' income was found below the Lhokseumawe City Minimum Wage in 2018 (54\%); and almost 58\% have graduated from high school. About $76 \%$ of housewives live in their own homes and only $34.7 \%$ of respondents answered that they knew there were dengue cases in their area.

\subsection{Knowledge of Risk Factors, Prevention in Humans, and Control of DHF}

Respondent's knowledge includes all things that are known about DHF, factors related to risk, the spread of DHF, symptoms of DHF in mosquitoes, humans, prevention and control of DHF. Based on the tabulation of frequency distribution of respondents 'knowledge variables, after data processing has been carried out, it is known that respondents' knowledge of dengue disease is in the medium category, which is only 42 respondents $(58.3 \%)$.

Table 1. Frequency of Distribution of Respondents Based on Their Knowledge of DHF Prevention in Muara Dua District, Lhokseumawe City in 2018

\begin{tabular}{|l|l|l|l|}
\hline No & Knowledge & F & Percentage $\%$ \\
\hline 1 & Less & 2 & 2,78 \\
\hline 2 & Fair & 42 & 58,33 \\
\hline 3 & Good & 28 & 38,89 \\
\hline \multicolumn{2}{|l|}{ Total } & $\mathbf{7 2}$ & $\mathbf{1 0 0}$ \\
\hline
\end{tabular}

\subsection{Attitude of Prevention of DHF}

Attitude is the tendency of respondents to respond (positively or negatively) to the DHF prevention program, including efforts to prevent the spread of DHF. The following is a description of the results of research in the form of tabulation of respondents' attitudes about efforts to prevent the spread of DHF. Based on the tabulation of the respondent's variable distribution, the results described that the attitude of respondents about efforts to prevent the spread of dengue disease is mostly in the medium category, which is 37 respondents $(51.3 \%)$.

Table 2. Frequency of Distribution of Respondents Based on Attitude and Perception of DHF Prevention in Muara Dua District, Lhokseumawe City in 2018

\begin{tabular}{|l|l|l|l|}
\hline No & Attitude and Perception & F & Percentage \% \\
\hline 1 & Less & 7 & 9,72 \\
\hline 2 & Fair & 37 & 51,39 \\
\hline 3 & Good & 28 & 38,89 \\
\hline Total & $\mathbf{7 2}$ & $\mathbf{1 0 0}$ \\
\hline
\end{tabular}

\subsection{DBD Prevention Participation}

The participation of housewives in the prevention of dengue describes participation in implementing a DHF prevention program such as draining and brushing the walls of water 
reservoirs such as: bathtubs and drums, closing water reservoirs (drums, jars) tightly and burying or stockpiling used goods and collecting used goods that can hold water and dispose of it to temporary disposal sites (TPS). Monitor and inspect water reservoirs as a breeding ground for Aedes aegypti mosquitoes such as bathtubs, drums, used tires, flower pots, dispensers and report families affected by DHF to the Community Service Center. The results revealed that the participation of respondents in the prevention of DHF is in the medium category, there are 50 respondents $(69.44 \%), 9$ respondents $(12.5 \%)$ are in the low category, but only 13 respondents $(18.06 \%)$ included in the good category in participation.

Table 3. Frequency of Respondent Distribution Based on Participation for DHF Prevention in Muara Dua District, Lhokseumawe City in 2018

\begin{tabular}{|l|l|l|l|}
\hline No & Pengetahuan & F & Percentage \% \\
\hline 1 & Less & 9 & 12,50 \\
\hline 2 & Fair & 50 & 69,44 \\
\hline 3 & Good & 13 & 18,06 \\
\hline Total & $\mathbf{7 2}$ & $\mathbf{1 0 0}$ \\
\hline
\end{tabular}

Based on the answers from the questionnaire and collected data, more than $75 \%$ of respondents lived in endemic areas, more than 68\% knew that DHF was transmitted through mosquitoes, but about $26.39 \%$ of respondents would seek treatment after the suspect was infected with DHF at the Public Health Center and only 23.61\% are aware of the need for DBN PSN. As many as 50\% of respondents knew 3M Plus as a tool to control DHF, but only $37.5 \%$ of respondents did $3 \mathrm{M}$ Plus even though they knew that $3 \mathrm{M}$ Plus needed to be continuously done throughout the year, especially in the rainy season. Correlation Analysis Pearson was also used to analyze the relationship between housewife characteristics including age, education, income, knowledge and attitudes with participation in DHF prevention programs. The results have been presented in Table 4.

Table 4. Analysis of Pearson Correlation Analysis between Characteristics of Household in Participation of DHF Prevention

\begin{tabular}{|l|l|l|l|}
\hline No & Variables & Correlation Pearson & Sig. (2-tailed) \\
\hline 1 & Education & $0,282^{*}$ & 0,016 \\
\hline 2 & Income & $-0,133$ & 0,265 \\
\hline 3 & Knowledge & $0,610^{* *}$ & 0,000 \\
\hline 4 & Attitude & $0,677^{* *}$ & 0,000 \\
\hline
\end{tabular}

*. The correlation was significant at $\mathrm{p}<0.05$

$* *$. The correlation is significant at $\mathrm{p}<0.01$

Based on the data in the table, it showed that there is a strong significant correlation between knowledge, attitude $(p<0.01)$ and a significant correlation in education $(p<0.05)$ from housewives with participation in the prevention of dengue. The high level of DHF cases in an area depends on several factors, such as public awareness in DHF PSN, community knowledge about the dangers of DHF, awareness and willingness to report ABJ cases (number of larva free) (Astuti, 2014). DHF is a disease in rural and urban areas. However, most DHF patients in the estuary two sub-district did not aware and never tried to seek for health care facilities to cure the disease. Community participation is an important element of the DHF control program [6]. Education, knowledge, and attitudes that influence the participation of housewives towards the prevention of dengue, indicate that this area is in dire need of health promotion which contains Information, Education and Communication (IEC) activities for DHF control, educating the public about the epidemiological features of DHF and simple 
preventive measures which can protect individuals and bring about a reduction in the overall incidence of DHF.

Communities must be aware of the importance of practices such as breaking the chain of mosquitoes by performing DHF DBN. Health promotion must be targeted and adapted to local social culture to facilitate IEC delivery $[18,19,20]$. Characteristic variables of housewives whose majority of respondents' income is below the minimum wage in Lhokseumawe City do not have an influence on their participation in the DHF prevention program is the income variable $(p=0.265)$ due to they are more worried if their children are affected by DHF and if they were attacked by DHF, the responsibility of medical cost would be on their own.

\section{Conclusion}

Respondents' participation in the prevention of DHF is in the medium category, which is 50 respondents (69.44\%), 9 respondents (12.5\%) are in the low category, but only 13 respondents $(18.06 \%)$ are in the good category in their participation. There is a significant relationship between knowledge, attitude $(\mathrm{p}<0.01)$ and a significant correlation in education $(p<0.05)$ from housewives who have been participated in the prevention of dengue. Variable characteristics of housewives who have no effect on their participation in the DHF prevention program are income variables $(p=0.265)$.

From the conclusion above, the suggestion can be drawn as follow: 1) DHF can be prevented by breaking the mosquito chain, PSN DBD is known as 3M Plus. 2) An advocacy program is needed to raise public awareness and political commitment to control DHF so that no outbreaks occur (extraordinary events), create an effective system for distributing information so that housewives are given timely and updated information on PSN extension schedules. 3) Collaboration between the medical sector, veterinary medicine, and the integration of local authorities to ensure the availability of prevention services, as well as public health to promote health prevention programs for dengue in the community in the following areas: danger of dengue fever and modes of its transmission to humans; the importance and usefulness of deciding the chain of mosquitoes; the importance of finding health facilities after suffering from dengue disease and providing support and community participation for dengue control programs.

\section{References}

Arikunto, S., 2013. Prosedur Penelitian Suatu Pendekatan Praktek. Cetakan II, Edisi 4, Rineka Cipta Jakarta.

Astuti, D. Siti Irene. 2014. Desentralisasi dan Partisipasi dalam Pendidikan. Yogyakarta: Pustaka Pelajar

Candra, A. 2013. Dengue Hemorrhagic Fever: Epidemiology, Pathogenesis, and Its Transmission Risk Factors. Aspirator, 2, 110-119.

CDC. 2014. Epidemiology DBD. https://www.cdc.gov/dengue/epidemiology/ index.html, accessed on 06 January 2018.

Dinkes Kota Banda Aceh. 2017. Jumlah penderita DBD selama 5 tahun terakhir. Banda Aceh: Dinas Kesehatan Kota Banda Aceh.

Dinkes Provinsi Aceh. 2017. Profil kesehatan Provinsi Aceh. Banda Aceh; Dinas Kesehatan Propinsi Aceh.

Dwiningrum, S.I.A. 2014. Modal Sosial dalam Pengembangan Pendidikan dalam Perspektif Teori dan Praktik. Yogyakarta: UNY Press.

Efriza. 2012. Political Explore, Sebuah Kajian Ilmu Politik. Cetakan Pertama. Bandung : 
Alfabeta.

Ghozali, I. 2015. Aplikasi Analisis Multivariete dengan Program IBM. SPSS 21. Semarang: Badan Penerbit Universitas Diponegoro

Ipa, M. 2017. Status Kerentanan Larva Aedes aegypti terhadap Temefos (Organofosfat) di Tiga Kabupaten/Kota Provinsi Aceh. ASPIRATOR, 9(2), 2017, pp. 77-84.

Josef, F.M. 2010. Partisipasi dalam Promosi Kesehatan pada Kasus Penyakit Demam Berdarah (DB) Ditinjau dari Pemberdayaan Psikologis dan Rasa Bermasyarakat. Jurnal Psikologi. 2010; 37(1) : $65-81$.

Kasjono, H.S. 2014. Hubungan Modal Sosial Dengan Partisipasi Pemberantasan Sarang Nyamuk Demam Berdarah Dengue Di Kabupaten Bantul. Prosiding - Semnas \& Call For Papers Prodi Kesehatan Masyarakat Fakultas Ilmu Kesehatan Poltekkes Kemenkes Yogyakarta.

, H.S. 2016. Promosi Kesehatan, Pemberdayaan Masyarakat, dan Modal Sosial. Cetakan Nopember 2016. Yogyakarta: Nuha Medika.

Kemenkes RI. 2012. Pemberantasan Sarang Nyamuk Demam Berdarah Dengue. Jakarta: Kementerian Kesehatan Republik Indonesia.

Kemenkes RI. 2013. Situasi Demam Berdarah Dengue di Indonesia. Jakarta: Pusat Data dan Informasi Kementerian Kesehatan RI.

Kemenkes RI. 2017. Data dan Informasi Profil Kesehatan Indonesia Tahun 2016. Jakarta: Kementerian Kesehatan Republik Indonesia.

Kristina, 2014. Kajian Masalah Kesehatan Demam Berdarah Dengue. Jakarta: Badan Penelitian dan Pengembangan Kesehatan Departemen Kesehatan Republik Indonesia.

Liza, A. 2015. Hubungan Tingkat Pengetahuan, Pendidikan Dan Sikap Dengan Partisipasi Ibu Rumah Tangga Dalam Pencegahan Wabah Dbd Di Kecamatan Kuta Alam Banda Aceh. Jurnal Kedokteran Syiah Kuala. 2015; 15(3): 135-141.

Megasari, M. 2013. Perbedaan Tingkat Pengetahuan Pencegahan Demam Berdarah Dengue (DBD) Dengan Metode Ceramah Dan Snowball Throwing Pada Anak Usia 6-12 Tahun Di Sdn Puger Kulon 01 Kabupaten Jember. Jember: Program Studi Ilmu Keperawatan Universitas Jember.

Notoatmodjo, S. 2013. Metodologi Penelitian Kesehatan. Cetakan Pertama. Jakarta: Rineka Cipta.

Notoatmodjo S, 2014. Promosi Kesehatan dan Ilmu Perilaku Kesehatan. Cetakan Kedua. Jakarta : Rineka Cipta.

Priyoto. 2014. Teori Sikap dan Perilaku Dalam Kesehatan. Cetakan Pertama. Yogyakarta: Nuha Medika

Pangemanan, J. 2014. Perilaku Masyarakat Tentang Program Pemberantasan Penyakit DBD di Kabupaten Minahasa Utara. Manado: Fakultas Kesehatan Masyarakat Universitas Sam Ratulangi.

Poerwadarminta. 2014. Kamus Umum Bahasa Indonesia. Jakarta: PN Balai Pustaka.

Sahrir, N. 2016. Pemetaan Karakteristik Lingkungan Dan Densitas Nyamuk Aedes Aegypti Berdasarkan Status Endemisitas DBD Di Kecamatan Kolaka. JST Kesehatan, Januari 2016, Vol. 6 No. 1: $70-75$.

Sidiek, A. 2012. Hubungan Tingkat Pengetahuan Ibu Mengenai Penyakit DBD Terhadap Kejadian Penyakit DBD Pada Anak. Semarang: Program Pendidikan Sarjana Kedokteran Fakultas Kedokteran Universitas Diponegoro.

Soedarto. 2015. Demam Berdarah Dengue (Dengue Hemorrhagic Fever). Jakarta: Sagung Seto.

Soegijanto, Soegeng. 2014. Demam Berdarah Dengue. Edisi Kedua. Surabaya Airlangga University Press.

Sugiyono. 2014. Metode Penelitian Kuantitatif Kualitatif dan R\&D. Bandung: Alfabeta. 
Trisnaniyanti, I. 2014. Persepsi Dan Aktifitas Kader PSN DBD Terhadap Pencegahan Dan Pemberantasan Demam Berdarah Dengue. Berita Kedokteran Masyarakat Vol. 26, No. 3, September 2014.

Wawan dan Dewi, 2011. Teori Pengukuran Pengetahuan, Sikap dan Perilaku Manusia, Cetakan Kedua. Yogyakarta: Nuha Medika.

WHO. 2015. Comprehensive Guidelines for Prevention and Control of Dengue and Dengue Haemorrhagic Fever.

Hanim, D. 2013. Program Pengendalian Penyakit Menular: Demam Berdarah Dengue. Surakarta: Fakultas Kedokteran Universitas Negeri Surakarta. 